\title{
Environmental Awareness and Concern over Transboundary Oil Spill in Bintan Island: a Preliminary Analysis Results
}

\author{
Dhani Akbar ${ }^{1}$, Azhari Setiawan ${ }^{2}$, Mariani Mariani ${ }^{3}$, Oksep Adhayanto $^{4}$, Okparizan Okparizan ${ }^{1}$, Wayu Eko Yudiatmaja ${ }^{5}$ \\ ${ }^{1}$ International Relations Department, Faculty of Social and Political Science, Universitas Maritim Raja Ali Haji. Jl. Raya Dompak, \\ Tanjungpinang, Kepulauan Riau Province. 29111. Indonesia, \\ ${ }^{2}$ International Relations Department, Faculty of Social and Political Science, Universitas Abdurrab. J1. Riau Ujung No. 73. \\ Pekanbaru. 28291. Indonesia. \\ ${ }^{3}$ Agribusiness Department, Faculty of Agriculture, Universitas Lambung Mangkurat. Jl. Jend. A. Yani, Banjarbaru. South \\ Kalimantan Province. 74713. Indonesia. \\ ${ }^{4}$ Law Department, Faculty of Social and Political Science, Universitas Maritim Raja Ali Haji. Jl. Raya Dompak, Tanjungpinang, \\ Kepulauan Riau Province. 29111. Indonesia, \\ ${ }^{5}$ Public Administration Department, Faculty of Social and Political Science, Universitas Maritim Raja Ali Haji. Jl. Raya Dompak, \\ Tanjungpinang, Kepulauan Riau Province. 29111. Indonesia.
}

\begin{abstract}
Regarding its strategic position which also has environmental potential and actual threats, Kepulauan Riau Province (Riau Island) is facing some challenges. This study discussed the environmental awareness and concern over transboundary oil spills case in Bintan Island, Kepulauan Riau. This study organized a regional cross-sectional survey exploring: (1) knowledge, (2) attitudes, (3) political attitudes, and (4) political perception in relation to transboundary oil spills case. This finding has an important implication for developing a more significant information and socialization on environmental politics and governance towards people in Bintan Island. It also argued that Awareness violates voting process, while, Party Identification and Concern have a positive impact on voting probability. The relevance of Awareness is supported by the inclusion of variable control even though our variable control were not significant.
\end{abstract}

Keyword : Maritime, Pollution, Environmental Awareness.

\section{Introduction}

Locating at the sea which connects the north-south economy, Kepulauan Riau Province could not avoid water pollution and harmed marine ecosystem issues. As the most crowded sea, regarding its strategic position, with environmental potential and actual threats, Kepulauan Riau Province (Riau Island) is facing some environmental challenges. One of its challenges is oil spills or oil waste problem. Oil waste problem also threatens the livelihoods of the people of Bintan, especially fishermen, due to marine ecosystems damaged by oil waste. The danger becomes more serious when microplastics are widespread and absorb Co-Pollutants.

In addition, the risk of microplastics spread may become more remarkable when co-pollution from other pollutant agents are absorbed onto the plastic surface polymer. As the main pollutant, oil may stick to the plastics as media of spreading and make the pollution become more attractive to biota. Besides fishermen, oil waste also snapping Kepulauan Riau tourism, which relies on sea tourism. The government of Kepulauan Riau Province has established Standard Operating Procedures (SOP) related to oil spills issues, including Law enforcement, AIS System, Port State Control, Oil Modelling, and Surveillance of next occurrence.
However, structural arrangements and law enforcement of No 32 Year 2009 regarding the Protection and Management of Environment [1], whether in national or subnational governments towards this annual case is remain weak [2] and the emersion of institutional design multi-level governance oriented was not fully implemented [3].
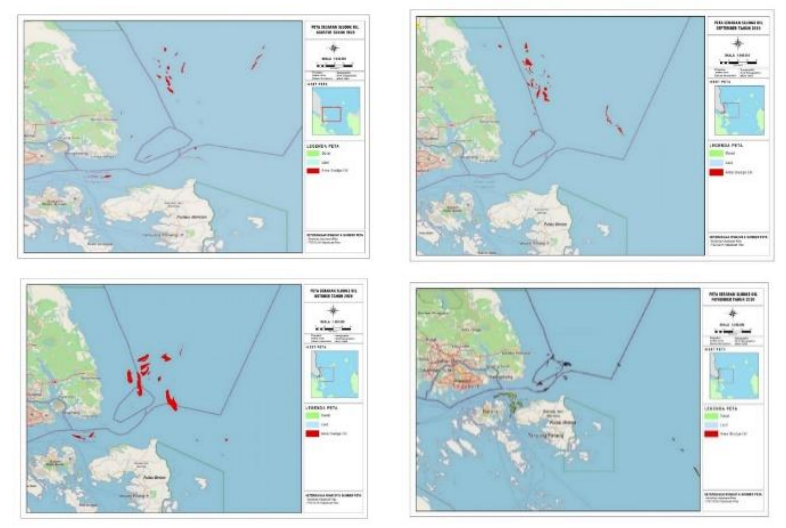

Figure 1. The picture of occurrences of oil spills in Bintan island, August - November 2020.

According to recent studies on Mely CaballeroAnthony et al; the environmental crisis is one of the non- 
traditional security issues called environmental security [4]. Our topic also has been discussed further as water security issues [5]. In their works, Mely CaballeroAnthony et al; examine how Asian states and societies are facing nine critical security challenges on: (1) health, (2) food, (3) water, (4) natural disasters, (5) internal conflict, (6) forced migration, (7) energy, (8) transnational crimes, and (9) cyber security. Instead of the 'statism-realists' approach, non-traditional security issues have to be considered and analysed from a different point of view, specifically from a human security perspective [4]. By this understanding, we noted that by exploring more on human's perspective and condition, we could get more explanation regarding factors or determinants occurring around the oil spills issues.

Besides understanding the political situation of the government in handling the oil spills crisis, studies on human behavior and perceptions in response to these occurrences are greatly compulsory. Public perception is essential to discover how it affects and changes personal behavior related to environmental problems [6]. Several works from health and psychology studies used the 'Knowledge-Attitudes-Practices' (KAP) model to analyse human repercussions on the certain cases [7][10]. A study about the haze crisis in Malaysia stated that public awareness has a positive impact on environmental protection support regarding air pollution in Peninsular Malaysia [8].

As can be seen, studies on human perception of the environmental crisis were highly developed. However, some works of the studies have lacked on depicting any systematic research into people's political perception and attitudes concerning environmental crisis and oil spills as well. Most studies highlighted how knowledge affects attitudes and how attitudes affect the environmental behaviors but not-or only few discussing - the political behaviours. We are concern about political aspects because most of the environmental crises occurred in developing countries [11] which are also struggling in political development (e.g., democratic consolidation, elections, human rights, economic disparity, etc.).

Several qualitative analyses about environmental politics and political economy have been developed, primarily regarding politics of haze [12][16]. We suppose a quantitative analysis on political behaviors related to awareness of, and concern about, the oil spills is required to fill the literature gap on the environmental politics research and contribute to the existing studies on oil spill politics and governance. Regarding the knowledge and attitude research instrumentation, we adopted the KAP approach [7], [17-18] to test the significant relationship between people's awareness and attitudes over the oil spills issues in Bintan Island, Kepulauan Riau Province.

The KAP also has been applied in our previous project discussing a similar topic [19]. Regarding to the political attitudes, we adopted research instrument from Burhanuddin Muhtadi's book, "Vote Buying in Indonesia: The Mechanics of Electoral Bribery" consisting: (1) party identification, (2) political efficacy, (3) political information, (4) political interests, (5) political trust, (6) political participation, and (7) democratic support [20] as the determinant of political bribery. We suggest using this research instrument to see whether highly politically active people tend to use their capacity and capability as voters to vote candidates that are perceived as right, proper, and appropriate candidates in terms of environmental politics and governance.

The central question in this research is to what extent Awareness, Concern, and Political Attitudes affect people to engage in political measures related to oil spills issues. Based on the works of literature review and our proposed study, this research seeks to test the three hypotheses as follow:

- The higher the awareness (knowledge) of the oil spills phenomenon, the higher the concern (attitudes) about it that people will report.

- The higher the awareness (knowledge) of, and concern (attitudes) over, the oil spills phenomenon, the more likely people will engage in political measures as a contribution solving the problem.

- People with higher political attitudes tend to engage into political measures related to oil spills issues.

We expected people are highly aware (higher level of knowledge) about oil spills issues, in regards its provenance, event and frequency of malignant episodes, impacts on economy, social and personal life, and consequences, will be more aware than people with a lower level of knowledge. We also presumed more excellent knowledge drives more concerns on the issues, which drive more people to engage in effective protective political measures (i.e., to vote for the candidate that is capable and knowledgeable on waste pollution management and practical ideas).

We also expected that people with higher political attitudes (highly politically active) in terms of party identification, political efficacy, political information, political interest, political trust, government support, and political participation, will be engaged in political measures related to oil spills issues. Government should develop cooperation and understanding with people to reduce the impact, especially in the climate change phenomena [21].

\section{Method}

By using a purposive sampling approach, the study interviewed 100 respondents in July 2020. The data collecting process conducted in Bintan Island, Kepulauan Riau Province. The survey ran about in one month, our team delivered a pencil-and-paper format interview method. Ten trained research assistants (RAs) hired to deliver the surveys. One of the author was appointed to evaluate and monitor survey whole process as the survey coordinator.

We organized a regional cross-sectional survey exploring: (1) knowledge, (2) attitudes, (3) political attitudes, and (4) political perception concerning the transboundary oil spills (details in table 1). Reliability tests and factor analysis were conducted for items in each explanatory/independent variable determine the sampling adequacy of data and to examine the natural factors generated from the variables. Afterward, we 
analyzed four models of binary logistic regression. The first three models applied each explanatory variableawareness of oil spills issues, concern over oil spills issues, and political attitudes - as one single model. The fourth model applied all explanatory variables as independent variables along with the sociodemographic characteristics of the respondents as the control variables. The dependent variable of the research is the respondent's probability of voting for candidates who are both capable and knowledgeable on environments and sustainable issues [19].

Table 1. Model of Analyses

\begin{tabular}{|l|l|l|l|}
\hline No & Independent & Indicators/Items & Dependent \\
\hline 1 & Knowledge & $\begin{array}{l}\text { Seven items on } \\
\text { Awareness of } \\
\text { oil spills issues }\end{array}$ & \\
\hline 2 & $\begin{array}{l}\text { Environmental } \\
\text { Attitudes }\end{array}$ & $\begin{array}{l}\text { Six items on } \\
\text { Concerns over } \\
\text { environmental } \\
\text { and oil spill } \\
\text { issues }\end{array}$ & $\begin{array}{l}\text { Vote for the } \\
\text { capable and } \\
\text { knowledgeable } \\
\text { candidate }\end{array}$ \\
\hline 3 & $\begin{array}{l}\text { Political } \\
\text { Attitudes }\end{array}$ & $\begin{array}{l}\text { Eight items on } \\
\text { Concerns } \\
\text { towards politics } \\
\text { in general }\end{array}$ & \\
\hline 4 & $\begin{array}{l}\text { All and } \\
\text { Controls }\end{array}$ & $\begin{array}{l}\text { All Independent } \\
\text { \& Control } \\
\text { Variables }\end{array}$ & \\
\hline
\end{tabular}

Regarding the Awareness, we developed an index for each knowledge variable and ran the preliminary analysis (reliability and factor analysis) in order to test the construct validity of the oil spills knowledge questionnaire; a principal axis factor analysis delivered on 7 (varimax rotation method). The Kaiser-MeyerOlkin Measure of Sampling Adequacy for the factor analysis is meritorious ( $\mathrm{KMO}=0.524)$. An initial analysis is ran to obtain eigenvalues for each factor, and small coefficients (absolute value $<0.4$ ) are suppressed. Three factors were then extracted from the factor of analysis rotation component matrix result.

Reliability analysis was done towards three factors producing for first factor (item 1-3), $\alpha=0.340$, for second factor (item $1,6,7$ ), $\alpha=-0.047$, and for the third factor (item 4,5 ), $\alpha=0.483$. The third factor is kept due to the reliability analysis result. The items clustering on this factor suggested that it represented concerning knowledge on the oil spills issues, so the valid and reliable Knowledge items average (index score) was calculated and labeled as 'Awareness towards Oil Spill Issues' or 'Awareness'.

Regarding the Concern, the Kaiser-Meyer-Olkin Measure of Sampling Adequacy for the factor analysis is meritorious $(\mathrm{KMO}=0.765)$. The factor analysis generated one component extracted and suggests that each item of attitudes variable is valid. We conducted analysis of reliability which generating 0.764 of Cronbach's alpha coefficient meaning that the items are reliable. These attitudes elements mean (index score) was calculated and labeled as 'Concern towards Oil Spill Issues' or 'Concern'.

\section{Result}

\subsection{Sample Demographics}

The research characteristics of respondents are summarized in Table 2. As can be seen in table 2 , the sample is distributed to $71 \%$ of males and $28.6 \%$ of females. $32.1 \%$ are students, $28.6 \%$ works in fisheries and most of the sample (47.6\%) live alone.

Table 2. Demographic Statistics of Respondents

\begin{tabular}{|l|l|c|c|}
\hline & & Frequency & Percent \\
\hline Gender & Female & 24 & 28.6 \\
\hline & Male & 60 & 71.4 \\
\hline & Laborer/Worker & 2 & 2.4 \\
\hline & Freelancer & 5 & 6.0 \\
\hline & $\begin{array}{l}\text { Private Sector } \\
\text { Employee }\end{array}$ & 10 & 11.9 \\
\hline & Local Government & 2 & 2.4 \\
\hline & Housewives & 4 & 4.8 \\
\hline & Fishermen & 24 & 28.6 \\
\hline & $\begin{array}{l}\text { State/Government } \\
\text { Employee }\end{array}$ & 1 & 1.2 \\
\hline & Student & 27 & 32.1 \\
\hline & Entrepreneur & 9 & 10.7 \\
\hline & 1 & 40 & 47.6 \\
\hline Dependents & 2 & 15 & 17.9 \\
\hline & 3 & 11 & 13.1 \\
\hline & $>3$ & 18 & 21.4 \\
\hline & $<$ IDR 1,000,000 & 27 & 32.1 \\
\hline & $\begin{array}{l}\text { IDR 1,000,000 - } \\
\text { IDR 2,000,000 }\end{array}$ & 11 & 13.1 \\
\hline & $>$ IDR 3,000,000 & $28,000-$ & 21.4 \\
\hline
\end{tabular}

Our essential question is to what extent Awareness, Concern, and Political Attitudes affect people probability of voting for so-called environmentally right candidate. We have three hypotheses to examine. The first hypothesis, people with deeper awareness of the oil spills issues tend to have higher concerns over oil spills. In order to prove the first hypothesis, a one-tailed correlation analysis. We analyzed the correlation of awareness and concern towards the oil spills issues, resulted the score was positively correlated, Pearson's $r(100)=186, p<0.05$. It suggests that the deeper knowledge on the oil spills issues that people have, the higher possibility that they will put the issues into concideration [19].

In terms of hypotheses 1 and 2, we ran a binary logistic regression analysis where "vote for the capable and knowledgeable candidate in terms of waste pollution management and effective ideas" were the dependent variable $(1=$ Yes, and $0=$ Not Vote $)$-will shorten as 'vote for the capable candidates.' The detail of our four logistic regression models presented in the following table 4 . The value presented in the table is the odds ratio and standard error in the parentheses. 
Table 3. Binary Logistic Regression Analyses Results

\begin{tabular}{|c|c|c|c|c|c|}
\hline & (1) & $(2)$ & (3) & (4) & $(5)$ \\
\hline VARIABLES & $\begin{array}{c}\text { Mode } \\
11\end{array}$ & $\begin{array}{c}\text { Mode } \\
12\end{array}$ & $\begin{array}{c}\text { Mode } \\
13\end{array}$ & $\begin{array}{c}\text { Mod } \\
\text { el } 4\end{array}$ & $\begin{array}{c}\text { Mode } \\
15\end{array}$ \\
\hline \multirow[t]{2}{*}{ Awareness } & $\begin{array}{c}- \\
1.765 \\
*\end{array}$ & $\begin{array}{c}- \\
1.822 \\
* *\end{array}$ & $\begin{array}{c}- \\
1.785 \\
*\end{array}$ & & $\begin{array}{c}- \\
1.621 \\
*\end{array}$ \\
\hline & $\begin{array}{c}(0.91 \\
7)\end{array}$ & $\begin{array}{c}(0.92 \\
5)\end{array}$ & $\begin{array}{c}(0.97 \\
0)\end{array}$ & & $\begin{array}{c}(0.96 \\
4)\end{array}$ \\
\hline \multirow[t]{2}{*}{ Concern } & & 0.178 & 0.618 & & $\begin{array}{c}1.350 \\
*\end{array}$ \\
\hline & & $\begin{array}{c}(0.41 \\
4)\end{array}$ & $\begin{array}{c}(0.56 \\
4)\end{array}$ & & $\begin{array}{c}(0.71 \\
3)\end{array}$ \\
\hline \multirow[t]{2}{*}{ PA_PartyIdentification } & & & $\begin{array}{c}0.710 \\
* *\end{array}$ & & $\begin{array}{c}0.630 \\
*\end{array}$ \\
\hline & & & $\begin{array}{c}(0.32 \\
9)\end{array}$ & & $\begin{array}{c}(0.33 \\
5)\end{array}$ \\
\hline \multirow[t]{2}{*}{$\begin{array}{l}\text { PA_InternalPoliticalEffic } \\
\text { acyReco }\end{array}$} & & & $\begin{array}{c}0.040 \\
9\end{array}$ & & $\begin{array}{c}0.009 \\
51\end{array}$ \\
\hline & & & $\begin{array}{c}(0.33 \\
0) \\
\end{array}$ & & $\begin{array}{c}(0.36 \\
7) \\
\end{array}$ \\
\hline \multirow[t]{2}{*}{$\begin{array}{l}\text { PA_ExternalPoliticalEffi } \\
\text { cacy }\end{array}$} & & & 0.442 & & 0.611 \\
\hline & & & $\begin{array}{c}(0.34 \\
0)\end{array}$ & & $\begin{array}{c}(0.39 \\
4)\end{array}$ \\
\hline \multirow[t]{2}{*}{ PA_PoliticalInformation } & & & $\begin{array}{c}0.059 \\
4\end{array}$ & & $\begin{array}{c}- \\
0.001 \\
85\end{array}$ \\
\hline & & & $\begin{array}{c}(0.38 \\
0) \\
\end{array}$ & & $\begin{array}{c}(0.43 \\
1) \\
\end{array}$ \\
\hline \multirow[t]{2}{*}{ PA_PoliticalInterest } & & & $\overline{-}$ & & $\begin{array}{c}- \\
0.238 \\
\end{array}$ \\
\hline & & & $\begin{array}{c}(0.39 \\
7) \\
\end{array}$ & & $\begin{array}{c}(0.42 \\
9) \\
\end{array}$ \\
\hline \multirow[t]{2}{*}{ PA_PoliticalTrust } & & & 0.627 & & 0.353 \\
\hline & & & $\begin{array}{c}(0.40 \\
6) \\
\end{array}$ & & $\begin{array}{c}(0.45 \\
9) \\
\end{array}$ \\
\hline \multirow[t]{2}{*}{$\begin{array}{l}\text { PA_SupportForGovernm } \\
\text { ent }\end{array}$} & & & 0.201 & & 0.595 \\
\hline & & & $\begin{array}{c}(0.31 \\
6) \\
\end{array}$ & & $\begin{array}{c}(0.39 \\
3)\end{array}$ \\
\hline \multirow[t]{2}{*}{ PA_PoliticalParticipation } & & & 0.716 & & 0.960 \\
\hline & & & $\begin{array}{c}(0.99 \\
3)\end{array}$ & & $\begin{array}{c}(1.07 \\
6)\end{array}$ \\
\hline \multirow[t]{2}{*}{ Gender } & & & & $\begin{array}{c}0.18 \\
7\end{array}$ & $\begin{array}{c}- \\
0.007 \\
90\end{array}$ \\
\hline & & & & $\begin{array}{c}(0.56 \\
5)\end{array}$ & $\begin{array}{c}(0.73 \\
6) \\
\end{array}$ \\
\hline \multirow[t]{2}{*}{ WorkInFisheries } & & & & $\begin{array}{c}- \\
0.54 \\
3\end{array}$ & 0.431 \\
\hline & & & & $\begin{array}{c}(0.63 \\
1)\end{array}$ & $\begin{array}{c}(0.91 \\
2)\end{array}$ \\
\hline \multirow[t]{2}{*}{ Dependents } & & & & $\begin{array}{c}0.33 \\
6\end{array}$ & 0.315 \\
\hline & & & & $\begin{array}{c}(0.23 \\
7)\end{array}$ & $\begin{array}{c}(0.30 \\
0)\end{array}$ \\
\hline \multirow[t]{2}{*}{ Income } & & & & $\begin{array}{c}0.39 \\
0\end{array}$ & 0.395 \\
\hline & & & & $\begin{array}{c}(0.23 \\
8)\end{array}$ & $\begin{array}{c}(0.30 \\
7)\end{array}$ \\
\hline \multirow[t]{2}{*}{ Constant } & $\begin{array}{c}2.024 \\
* *\end{array}$ & 1.374 & $\begin{array}{c}- \\
5.580 \\
*\end{array}$ & $\begin{array}{c}- \\
1.04 \\
0\end{array}$ & $\begin{array}{c}- \\
11.36 \\
* *\end{array}$ \\
\hline & $\begin{array}{c}(0.83 \\
3)\end{array}$ & $\begin{array}{c}(1.71 \\
2)\end{array}$ & $\begin{array}{c}(3.21 \\
8)\end{array}$ & $\begin{array}{c}(0.67 \\
5)\end{array}$ & $\begin{array}{c}(4.66 \\
7) \\
\end{array}$ \\
\hline Observations & 100 & 100 & 100 & 100 & 100 \\
\hline
\end{tabular}

Dependent Variables: coded as "1" for Vote; and " 0 " for Not Vote for capable and knowledgeable candidates regarding waste pollution management and practical ideas. $* * * p<0.01$, $* * p<0.05, * p<0.1$.

\section{Discussion}

Based on the binary logistic regression analysis presented in table 4, Model 1 where we analyzed awareness toward people's probability to vote capable candidate shows negative and statistically significant results. This means that people's awareness does not lead them to participate in the election to vote a candidate who perceived capable and knowledgeable in handling the oil spill issues. A possible explanation for the result could be explained by what happens in item 3 , 5 , and 6 in political attitude variables, where people are divided into fifty-fifty parties in term of political participation even though most of all respondents were politically active on keeping up the politics in term of issues, news, and discussions. Model 1 result has the same significance with the Model 2, where Awareness has a negative significant impact on people's probability to vote after adding the Concern Variable into Model 2.

Since political participation in political attitude variables is interesting, we added political attitudes into Model 3. The results, as shown in Table 4, Model 3, indicate that Awareness and Party Identification (Party ID) have a significant impact toward people's vote. Interestingly, our finding in Model 3 suggests that even though awareness precisely does not lead to people's intention to vote in election, Party Identification could increase the probability to vote. The more people perceive attachement to certain political parties and/or politicians, the more likely they will vote for the candidate(s). This finding indicates Party Identification could bridge people trust and interest in politics to more active political participation.

In Model 4, we analyzed socio-demographic characteristics as the control variables. Since there is no significant estimation result in Model 4, we tried to append it into Model 5, where all explanatory variables and control variables were analyzed. Surprisingly, although control variables inclusion does not change the estimates of our explanatory variables in Model 4, in Model 5, Concern becomes significant and have positive impact on increasing the probability to vote. Based on this finding, we kept the control variables in Model 5. Our final finding suggests that Awareness, Concern, and Party Identification respectively have significant impact on probability of voting in the forthcoming election. An interesting finding on Awareness could be an opportunity for further studies by analyzing Concern as intervening variable in a Structural Equation Model or Path Analysis.

\section{Conclusion}

This research has argued that Awareness has a negative impact on voting, while, Concern and Party Identification have a positive impact on voting probability. The relevance of Concern is supported by the control variables inclusion even though our control variables were not significant. The present study confirms some previous findings and contributes additional evidence that suggests Party Identification of Political Attitudes as significant determinant to increase the probability of political action towards environmental politics and governance. 
This finding has important implication for developing a more significant information and socialization on environmental politics and governance towards people in Bintan Island. More significant information could lead to more significant concern which could encourage specific political actions or measures. One of the issues that emerge from these finding is the importance of Party Identification. Political Parties leaders urged to increase their relation to the society and the constituents to create a better political development between all stakeholders in term of environmental politics and governance, especially for oil spill issues in Bintan Island, Kepulauan Riau Province. Government and NGOs have to support and promote the conservation and sustainable use of the oceans, seas and marine resources following United Nations Sustainable Development Goals 14. The program's goals can be used to drive ocean innovation, strengthen youth involvement in the ocean sector, increase ocean literacy, and support new models of financially sustainable ocean conservation. This local community's perception of the problem may be an emphasis on creating a post-assessment mitigation proposal.

\section{References}

1. D. Akbar, Irman, W. E. Yudiatmaja, and K. Fadli, IOP Conference Series: Earth and Environmental Science 724, 012103 (2021).

2. W. E. Yudiatmaja, Yudithia, T. Samnuzulsari, and Suyito, IOP Conference Series: Earth and Environmental Science 423, (2020).

3. W. E. Yudiatmaja, T. Samnuzulsari, Suyito, and Yudithia, IOP Conference Series: Earth and Environmental Science 423, (2020).

4. M. Caballero-Anthony, An Introduction to NonTraditional Security Studies: A Transnational Approach (SAGE Publications, Singapore, 2016).

5. M. Caballero-Anthony and A. Cook, NonTraditional Security in Asia: Issues, Challenges and Framework for Action (Institute of Southeast Asian Studies (ISEAS), Singapore, 2013).

6. M. Caballero-Anthony, An Introduction to NonTraditional Security Studies: A Transnational Approach (SAGE Publications, Singapore, 2016).

7. K. Bickerstaff and G. Walker, Global Environmental Change 11, 133 (2001).

8. L. De Pretto, S. Acreman, M. J. Ashfold, S. K. Mohankumar, and A. Campos-Arceiz, PLoS ONE 10, 1 (2015).

9. Y. S. J. Chin, L. De Pretto, V. Thuppil, and M. J. Ashfold, PLoS ONE 14, 1 (2019).

10. S. A. Haron, L. Paim, and N. Yahaya, International Journal of Consumer Studies 29, 426 (2005).

11. N. ul Haq, M. A. Hassali, A. A. Shafie, F. Saleem, M. Farooqui, and H. Aljadhey, BMC Public Health 12, 692 (2012).

12. Y. S. J. Chin, L. De Pretto, V. Thuppil, and M. J. Ashfold, PLoS ONE 14, 1 (2019).

13. WHO, Who (2010).
14. H. Varkkey, Oxford Research Encyclopedia 25 (2017).

15. H. Varkkey, MJIR | Malaysian Journal of International Relations; Vol 4 No 1 (2016): MJIR | The Malaysian Journal of International RelationsDO - 10.22452/Mjir.Vol4no1.8 (2016).

16. H. Varkkey, Asia Pacific Viewpoint 53, 314 (2012).

17. A. Tyson, H. Varkkey, and S. A. B. Choiruzzan, Contemporary Southeast Asia 40, 422 (2018).

18. H. Varkkey, A. Tyson, and S. A. B. Choiruzzad, Forest Policy and Economics 92, 148 (2018).

19. A. Launiala, Anthropol Matters 11, 1 (2009).

20. WHO, A Guide To Developing Knowledge , Attitude and Practice Surveys (World Health Organization, Switzerland, 2008).

21. L. De Pretto, S. Acreman, M. J. Ashfold, S. K. Mohankumar, and A. Campos-Arceiz, PLoS ONE 10, 1 (2015).

22. D. Akbar, A. Setiawan, R. Prayuda, A. Putra, A. Aznor, and W. E. Yudiatmaja, Journal of Physics: Conference Series 1655, (2020).

23. B. Muhtadi, Vote Buying in Indonesia: The Mechanics of Electoral Bribery, 1st ed. (Palgrave Macmillan, Singapore, Singapore, 2019).

24. T. Samnuzulsari, D. Kristanti, H. Susanto, W. E. Yudiatmaja, M. K. Yunanto, S. D. Meilinda, and D. Akbar, IOP Conference Series: Earth and Environmental Science 824, 012104 (2021). 